\title{
THE 1954 MEETING OF THE BRITISH ASSOCIATION IN OXFORD
}

\author{
By DR. D. B. HARDEN
}

$\mathrm{T}$ $\mathrm{HE}$ meeting of the British Association which takes place in Oxford during the week September 1-8 will be the sixth time when the Association has met in that eity. The first time that Oxford was the host was in 1832, and the other four meetings have occurred at more or less regular intervals since then -in 1847, 1860, 1894 and 1926. Each one of these has had its own successes and its own value for members who attended, for scientists in general, and for the public at large.

In 1832 the president was Dr. W. Buckland, one of the pioneers of the modern study of geology and archæology, who at that time held the University readerships in geology and mineralogy and was later to become Dean of Westminster-truly an appropriate mixture of church and science for choice as president of the new Association (which had only been founded the year before at York). Yet it is recorded that another churchman, John Keble, did not take so kindly to the Association's visit in 1832 and thought it a pity that Oxford should not only receive "the hodge-podge of philosophers", as he called them, but even give some of them honorary degrees.

The second meeting, fifteen years later, presided over by Sir Robert Inglis, was important not only in itself, but also because of the stimulus it gave to the movement, led by Sir Henry Acland, for the reform and advancement of science teaching in Oxford-a movement that was to lead to the foundation of the new University Museum in the Parks as a centre for scientific research and teaching. Its foundation-stone was laid in 1855 and the building was virtually completed by 1860 , in which year, most appropriately, the third Oxford meeting of the Association was one of the first activities to take place within its walls.

This 1860 meeting, with Lord Wrottesley in the presidential chair, saw church and science at greater loggerheads than ever. The new museum-to-day once more to be used for British Association addresses -was (as a tablet on the wall of its west corridor records) the scene of acrimonious debate between Samuel Wilberforce, Bishop of Oxford, and T. H. Huxley and others, in which the honours certainly rested with the scientists.

The 1894 meeting, with the Marquis of Salisbury as president, was a quieter affair and has apparently left little mark behind it, though it attracted a membership of 2,321 , which for those times was good but by no means a record. Then in 1926 the fifth meeting, presided over by the Prince of Wales, and with men like Prof. (now Sir John) Graham Kerr, Sir Josiah Stamp and Sir Thomas Holland as sectional presidents, touched a further high peak, with what was then the second highest attendance $(3,722)$ of any meeting in the British Isles, being only surpassed by Manchester's total of 3,838 in 1887. Its memory is still green in the Association's annals, and if this 1954 meeting leaves visiting members equally happy and satisfied with its results, those in the University and in the City who are combining in the task of organizing it need have no complaint and no searchings of heart.

The president this year, Dr. E. D. Adrian, who will speak on "Science and Human Nature", is bound to have an attentive and enthusiastic audience in the Sheldonian, as well as in the 'Town Hall to which his address will be televised in full. A local television of this kind to an overflow audience was also staged at Edinburgh in 1951, and with outstanding success; but this year will be the first time that the conferment of honorary degrees and the beginning of the president's address at the inaugural meeting will be seen by all television viewers in Great Britain, at the same time as the whole address is being broadcast on sound radio to Britain and overseas. The B.B.C. also hopes to stage a series of television programmes from Oxford on other evenings during the meeting, as well as the usual sound broadcasts.

There will be evening discourses by Prof. W. E. Le Gros Clark on "Reason and Fallacy in the Study of Fossil Man", and by Dr. F. P. Bowden on "Friction", and among the sectional presidential addresses mention may be made of Sir John Cockeroft's to Section A on "Recent Developments in High Energy Physics", Dr. G. R. de Beer's to Section D on "Archæopteryx and Evolution", Prof. J. A. Steer's to Section E on "The Coast and the Geographer", and Sir Mortimer Wheeler's to Section H on "Archæology in Africa". These and other presidential addresses, and the many other papers by speakers in the sixteen sections and sub-sections into which the Association's meetings are now divided, will provide sufficiently varied fare to interest and instruct all the visiting scientists and laymen who come to Oxford for the occasion. Great numbers of them are, indeed, expected, and arrangements have been made to house more than two thousand in colleges of the University, if they so wish, while the remainder can be accommodated in the city's many hotels and boarding houses.

The sectional meeting-rooms will all be in or near the Science Area between Parks Road and South Parks Road; and with small distances separating the sections, those-and they are many-who like to divide their attention between various sections will find it easier to do so this year than in some previous ones. As the reception room is to be in Rhodes House, which is also in South Parks Road, members will find that everything will conspire to encourage them to attend more meetings than ever before.

A number of temporary exhibitions will be staged in the Bodleian Library and in the museums and science departments of the University, and should provide members with many interesting things to see and study, over and above the normal exhibitions of art, archæology, science and bibliography which are on permanent show in these institutions.

On the entertainment side-for scientists like others need time for relaxation, and use it at these British Association meetings to great profit as a chance for meeting old friends and making new ones, and for discussing their work and their problems with one another-there will be the usual series of general and sectional excursions to places of interest in the Oxford district, evening functions in the University Museum and in the Ashmolean Museum, a garden party in Trinity and St. John's Colleges and a subseription dance at the Town Hall, as well as numerous 
sectional dinners, private parties and other social events.

It has become the rule of late for the host centre to use the occasion of the Association's visit to produce an up-to-date and authoritative survey of the scientific and natural and human history of its district. The local executive committee at Oxford has charged its publications sub-committee with this task, and the volume, which is being wholly financed in generous fashion by the Delegates of the Clarendon Press, is now well advanced and will provide members with a finely balanced survey which should greatly enhanco their understanding and appreciation of what they see and hear during their time in Oxford.

The meeting takes place in Oxford itself, and most, if not all, of the visitors will be accommodated within or not far beyond the modern bounds of the city. But as the contents of the regional survey will emphasize, the real venue of the meeting is the Oxford district, that is, the country between Cotswolds, Chilterns and Berkshire Downs, and it is hoped that not only the excursions but also not a few of the lectures and addresses will enable members to get a picture of the natural and human history, both ancient and modern, of the upper Thames valley. Within that valley are other towns besides Oxford, and these towns, too, are to some, though necessarily to a lesser, extent hosts to the visitors from farther afield. Two of them in particular, Reading and Abingdon, are co-operating directly in one way or another with the University and civic authorities in Oxford in the arrangements for the meeting. It is the wish of all who are concerned in those arrangements that they shall lead to a meeting which will stand comparison with any one of the preceding five visits of the Association to Oxford. If the number of visitors equals or exceeds that of 1926 , the success of the 1954 meeting can scarcely fail to be assured.

\section{TOXIC CHEMICALS IN AGRICULTURE AND THEIR EFFECT ON FOODSTUFFS}

D

URING recent years a wide variety of chemicals has become available for the protection of growing crops or stored food. Thus insecticides, weed killers and fungicides are applied to agricultural crops, fruits and vegetables; chemicals known as 'sprout-depressants' are applied to stored potatoes ; other stored foods, such as grain, are fumigated, sprayed or dusted with insecticides. To these must be added the bacterial and chemical preparations used against rats which infest food stores. Substances or preparations having the above functions may be conveniently grouped together as pesticides.

The older pesticides were largely inorganic compounds containing lead, arsenic, copper or other metallic salts; and over the course of time methods have been standardized for the accurate determina. tion of metallic residues, and toxicity studies have led to the proposals (by the Metallic Contamination Sub-Committee of the Food Standards Committee of the Ministry of Food) for upper working-limits for such residues in foodstuffs. The precautions necessary in the use of these older pesticides are by now well established.

This is by no means true of the newer pesticides, which are usually organic chemicals highly effective in small concentrations. They present three distinct, although allied, hazards : to agricultural and other workers responsible for their use on the farm or in the food warehouse; to the consumer of food contaminated by residues; and to domestic animals and wild life-birds and useful insects may be killed and the ecological pattern in an area may be modified. Because of these considerations, the Minister of Agriculture and Fisheries in 1950 took the initiative in establishing a working party, under the chairmanship of Prof. S. Zuckerman, to examine the safety of workers dealing with pesticides ; many of the recommendations contained in its report published in $1951^{1}$ were given statutory authority by the Agricultural (Poisonous Substances) Act of 1952.

The working party was re-established in 1951 jointly by the Minister of Agriculture and Fisheries, the Minister of Health, the Minister of Food and the Secretary of State for Scotland to examine the second phase of the problem, namely, the potential hazards arising from the contamination of food with pesticide residues. The report* now issued gives a concise and authoritative survey of existing knowledge. A third report is being prepared on matters affecting animal and plant life.

Many who have been concerned directly or indirectly with pesticides have commented on the lack of available publications concerning their use in the United Kingdom - in contrast, for example, to the United States, where the various public inquiries ${ }^{2}$ have had the merit of providing information for both scientific workers and others interested. The working party affirms the fact that pesticides "can be marketed and used on food crops without any reference to official bodies" and that the many government departments concerned with the problem "have no means of obtaining adequate information about the introduction of new preparations except by the goodwill of the firm concerned". The emphasis placed on the necessity of reducing the "area of ignorance about crop-protecting chemicals" will therefore be warmly welcomed by those scientific workers who believe that the lack of information is one of the legitimate reasons for criticism and fear on the part of certain sections of the general public in Great Britain.

The report includes a valuable seven-page section listing the main compounds used as pesticides, classified according to their chemical constitution; an outline is given of their functions and modes of action. This list includes the rapidly growing numbers of the halogenated hydrocarbons (such as DDT and $\mathrm{BHC}$ and the increasingly important organophosphorus compounds (including 'Parathion' and 'Schradan'). As the working party points out, there is a formidable problem facing the analyst concerned with the identification of many of the newer compounds and with their determination at the low concentrations at which they are likely to occur as residues ${ }^{3}$.

A further difficulty arises from the lack of knowledge regarding the mode of action of many of the newer substances. Although much research has been carried out on selective toxicity ${ }^{4}$, some of the most effective agents for the control of lower organisms are known to interfere with enzyme systems which form a biochemical pattern throughout a wide range of mammalian and other species. Thus, some of the

* Toxic Chemicals in Agriculture: Residues in Food. (Report to the Ministers of Agricuiture and Fisheries, Fealth, and Food, and to the Secretary of State for Scotland, of the Working Party on PrePp. ili +32 . (London: H.M.S.O., 1953.) 